\title{
CHANGES IN MOTOR SKILLS OF BOYS WHO TRAINED SPORTS SWIMMING IN AN ANNUAL TRAINING CYCLE
}

\author{
Paweł Eider \\ Faculty of Physical Culture and Health Promotion, University of Szczecin, Poland \\ Address for corpespondence: \\ Paweł Eider, PhD \\ University of Szczecin, Faculty of Physical Culture and Health Promotion \\ Al. Piastów 40b, bulding 6, 71-065 Szczecin, Poland \\ E-mail: pawel.eider@univ.szczecin.pl
}

\begin{abstract}
Ahstract. This paper presents an empirical approach to the changes in motor skills of children who trained sports swimming at the initial stage of school education in an annual training cycle. The research included 94 boys aged 7 (1st grade of elementary school); 57 of them belonged to the Swimmers group and 37 belonged to the Control group. All boys attended elementary schools in Szczecin, Poland. Motor skills were assessed with 8 tests of the EUROFIT Test Battery. The study resulted in the following conclusions:

I. Dynamics of changes in terms of overall balance, static strength, functional strength (between Examination I and II) was greater in the Swimmers group.

II. In terms of upper limb movement, agility, explosive strength, torso strength, and agility run, differences between results of both examinations were similar in the Swimmers and Control groups.

III. Progressive changes in motor skill of subjects were a positive phenomenon in the physical development of children. Thus, swimming trainings significantly impacted dynamics of positive changes in motor skills of boys at the early stage of school education.

IV. Regular participation in sports classes (including swimming classes) had positive impact on motor skill development of children, which is of utmost importance at that age.
\end{abstract}

Key worlls:" selection, motor skills, swimming

\section{Introduction}

Effects of trainers' work depend largely on a correct selection process for sports swimming, and on professional, multi-step selection at a later stage (Eider 2014). It is easier and more effective to cooperate with athletes who possess qualities of the 'champion model' - Olympic and World Championship medalists. During many years of swimming trainings, focus should be placed on those characteristics of the body which are stable and developed by training (Opyrchał et al. 2005; Eider 2015). 
Competitive swimming is an Olympic sport, trained by numerous athletes in Poland (Sprawozdanie 2012). Szczecin, Poland, is one of the cities that have strong traditions and achievements and where Municipal Swimming Club (MKP) operates. Every year, the club wins numerous medals in swimming competitions in various age categories, including juniors, adolescents and seniors. The most awarded swimmers from Szczecin are the Olympic medalists, Melbourne 2007 World Champions, Mateusz Sawrymowicz (1,500 m freestyle) and Przemysław Stańczyk (800 m freestyle) (Eider and Eider 2012).

Competitive swimming is one of the Olympic sports which need early selection (at the age of 5-7 years) and specialization (Volbekiene 2007; Vranešić-Hadžimehmedović et al. 2012). The biggest sports events - the Olympic Games - offer as many as 102 medals for swimmers; there are 17 competitions for women and 17 for men (Janicka and Lewandowski 2012). Thus, for various reasons, National Swimming Associations in majority of countries are interested in training future representatives - hopefully medalists - who would promote their countries 'through sport'.

Szczecin is home to many Polish representatives, including participants of the Olympic Games, World and Europe Championships. Among Olympic athletes one can list: Dorota Brzozowska - Moscow 1980, Marta Włodkowska - Barcelona 1992, Przemysław Stańczyk - Athens 2004, Beijing 2008, Katarzyna Baranowska Beijing 2008, Mateusz Sawrymowicz - Beijing 2008, London 2012, and Oskar Krupecki - London 2012. Among Melbourne 2007 World Championship medalists there are: Mateusz Sawrymowicz (1500 m freestyle) and Przemysław Stańczyk (800 m freestyle). All of these athletes were members of Municipal Swimming Club in Szczecin. It is the largest and most awarded swimming club in Zachodniopomorskie voivodship. Every year, it achieves high ranks in national competitions in various age categories. (Ankieta 2013). Many medals were won by swimmers during Junior and Senior Europe Championship ( $25 \mathrm{~m}$ pool). The following seniors won gold medals: Katarzyna Baranowska - Trieste 2005, Helsinki 2006, Mateusz Sawrymowicz - Debrecen 2007, Szczecin 2011 (Drozd 2007; Eider 2009).

The aim of this study was to determine what changes in motor skills occurred in 7-year-old boys who trained swimming at the Municipal Swimming Club during a 1-year training cycle.

\section{Material and research methods}

Subject group consisted of 94 boys aged 7 who attended four elementary schools in Szczecin. The Swimmers group was 57-strong; boys trained at the Municipal Swimming Club (MKP) in Szczecin. The Control group consisted of 37 boys who attended the same elementary schools. The Control group members were selected based on the age of the Swimmers group members, with 3 months' precision; all subjects attended the same grade (1st of elementary school). Children from the Control group did not participate in any sports/recreation classes.

All subjects took part in two examinations (Table 1), carried out in the 2009/2010 academic year among 1st graders of Elementary Schools no. 51, 55, 56 and 62 in Szczecin (five swimming groups and four control groups). Examination I was conducted in September 2009, immediately after selection of Swimmers and Control groups (1st graders), while Examination II took place in June 2010, i.e. at the end of the 1st grade. The analysis included only those children who participated in both examinations. 
Physical ability tests were conducted in gyms where they were preceded by standard warm-up for all children (7-8 minutes). The tests were as simple as possible and required minimal equipment.

Motor skills were assessed with 8 tests of the EUROFIT Test Battery (Grabowski and Szopa 1991):

- General balance - Flamingo Balance Test - keeping balance while standing on one leg on a beam of certain dimensions.

- Speed of upper limb movements - Plate Tapping Test - touching quickly two purposefully placed plates with the preferred (stronger) hand.

- Flexibility - Sit-and-Reach Test - sitting and reaching forward as far as possible.

- Explosive leg power - Standing Broad Jump Test - broad jump from a standing position.

- Static strength - Handgrip strength test - gripping forcefully a dynamometer.

- Torso strength - Sit-Up Test - lying on the back and doing max. number of sit-up within 30 seconds.

- Functional strength - Bent Arm Hang Test - total time of maintain the hang position with bent arms on a bar.

- Agility run - $10 \times 5$ m Shuttle Run Test - running with max. speed and changes of direction.

Table 1. Number of boys in Swimmers and Control groups during examinations

\begin{tabular}{|c|c|c|c|c|}
\hline \multirow{2}{*}{ School } & \multirow{2}{*}{ Group } & \multirow{2}{*}{ Class number } & \multicolumn{2}{|c|}{ Examination } \\
\hline & & & 1 & II \\
\hline \multirow{4}{*}{ El. Sch. 51} & Sw & $1 a$ & 10 & 10 \\
\hline & Sw & $1 b$ & 10 & 10 \\
\hline & $C$ & 1c & 6 & 6 \\
\hline & $C$ & $1 d$ & 8 & 8 \\
\hline El. Sch. 51 & Sw & $1 \mathrm{a}$ & 14 & 14 \\
\hline \multirow{2}{*}{ El. Sch.56 } & Sw & $1 \mathrm{a}$ & 13 & 13 \\
\hline & $C$ & $1 b$ & 13 & 13 \\
\hline El. Sch. 62 & Sw & $1 a$ & 10 & 10 \\
\hline El. Sch. 56 & $C$ & $1 \mathrm{c}$ & 10 & 10 \\
\hline Total & & & 94 & 94 \\
\hline
\end{tabular}




\section{Research results}

\section{Flamingo Balance Test - genepal balance}

In both groups (Sw, C), Examination I and II revealed that average balance test results were insignificantly lower in the Swimmers group. Examination II proved statistically significant improvement of results in both groups $(\mathrm{Sw}, \mathrm{C})$ in comparison to Examination I (Table 2). In the Swimmers group, it was on average 2.8 attempts, while in the Control group it was $1.9(p=0.0004)$ (Figure 1).

Table 2. Descriptive characteristics of Flamingo Balance Test (general balance) in the Swimmers and Control groups

\begin{tabular}{|c|c|c|c|c|c|c|c|}
\hline & \multirow{2}{*}{ Distribution type } & \multicolumn{2}{|c|}{ Examination I } & \multicolumn{2}{|c|}{ Examination II } & \multicolumn{2}{|c|}{ Examination I vs. examination II } \\
\hline & & Sw & $\mathrm{C}$ & Sw & $\mathrm{C}$ & Sw & C \\
\hline \multirow{5}{*}{ Boys } & $\mathrm{n}$ & 57 & 37 & 57 & 37 & & \\
\hline & $\min -\max$ & $4.0-9.0$ & $4.0-9.0$ & $2.0-7.0$ & $2.0-9.0$ & & \\
\hline & mean & 8.0 & 8.0 & 4.0 & 6.0 & & \\
\hline & $\bar{X}(S D)$ & $7.5(1.1)$ & $8.0(1.1)$ & $4.7(1.2)$ & $6.1(1.3)$ & & \\
\hline & ss & \multicolumn{2}{|c|}{0.074} & \multicolumn{2}{|c|}{$<0.0001$} & $<0.0001$ & $<0.0001$ \\
\hline
\end{tabular}

SW - Swimmers, C - Control, min - minimum value, max - maximum value, $\bar{X}$ - arithmetic mean, SD - standard deviation, ss - statistical significance.

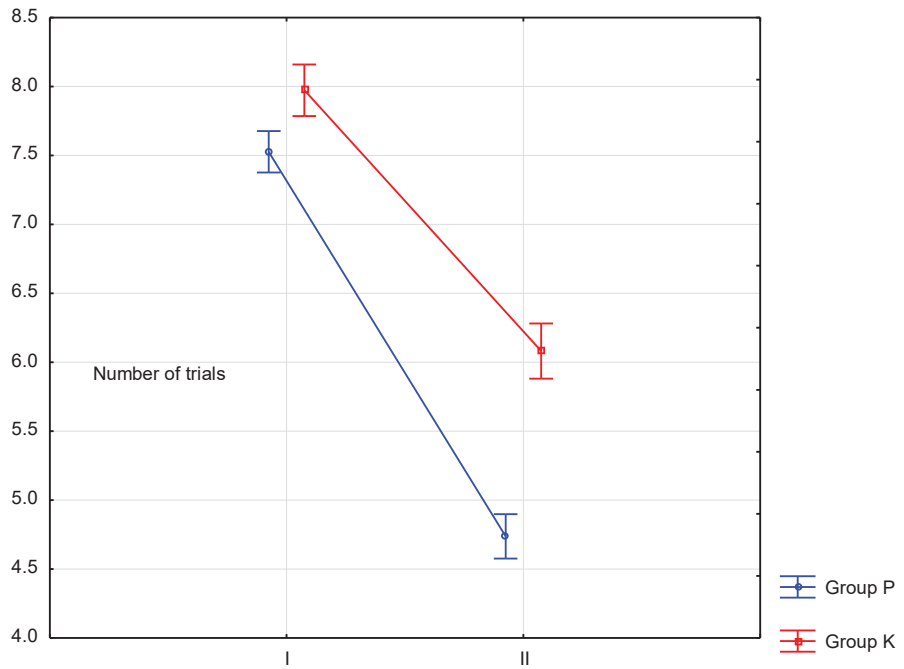

Figure 1. Changes in results of Flamingo Balance Test (general balance) in Swimmers (Sw) and Control (C) groups 


\section{Plate Tapping Test - speed of upper limb movements}

Examination I revealed that average results of upper limb movement results were significantly lower (shorter time) in the Swimmers group. Examination II revealed statistically better results of boys from the Swimmers group. Examination II proved statistically significant improvement of results in both groups (Sw, C) in comparison to Examination I (Table 3). In the Swimmers group, it was on average $1.4 \mathrm{~s}$, while in the Control group it was $1.3 \mathrm{~s}$ $(p=0.280)$ (Figure 2).

Table 3. Descriptive characteristics of Plate Tapping Test (speed of upper limb movements) results in the Swimmers Group (Sw) and Control group (C)

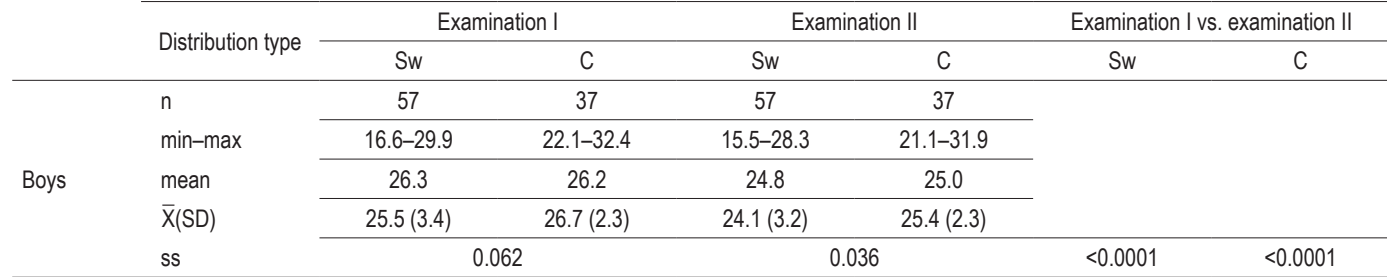

Sw - Swimmers, C - Control, min - minimum value, max - maximum value, $\bar{X}$ - arithmetic mean, SD - standard deviation, ss - statistical significance.

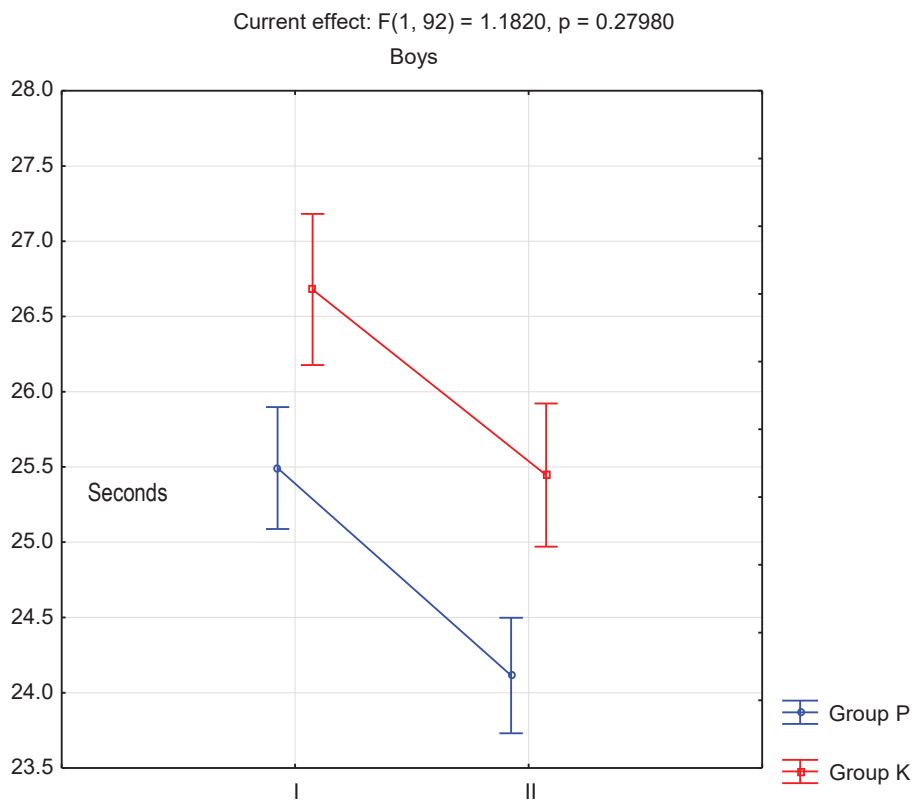

Figure 2. Changes in the results of Plate Tapping Test (speed of upper limb movements) in the Swimmers group (Sw) and Control group (C) 


\section{Sit-and-Reach Test - flexibility}

Swimmers group displayed statistically significantly better results in Examination I and II in terms of torso flexibility. Examination II proved statistically significant improvement of results in both groups (Sw, C) in comparison to Examination I (Table 4). In the Swimming Group, it was on average $5.1 \mathrm{~cm}$, while in the Control group it was $4.5 \mathrm{~cm}(p=0.241)$ (Figure 3).

Table 4. Descriptive characteristics of Sit-and-Reach Test (flexibility) results in Swimmers (Sw) group and Control (C) group

\begin{tabular}{|c|c|c|c|c|c|c|c|}
\hline & \multirow{2}{*}{ Distribution type } & \multicolumn{2}{|c|}{ Examination I } & \multicolumn{2}{|c|}{ Examination II } & \multicolumn{2}{|c|}{ Examination I vs. examination I } \\
\hline & & Sw & C & Sw & C & Sw & C \\
\hline & $n$ & 57 & 37 & 57 & 37 & & \\
\hline & $\min -\max$ & $-16.0-12.0$ & $-18.0-11.0$ & $-10.0-17.0$ & $-15.0-15.0$ & & \\
\hline \multirow[t]{3}{*}{ Boys } & mean & 2.0 & -4.0 & 5.0 & 2.0 & & \\
\hline & $\bar{X}(S D)$ & $-0.6(6.6)$ & $-3.5(6.5)$ & $4.5(6.2)$ & $1.0(6.2)$ & & \\
\hline & ss & \multicolumn{2}{|c|}{0.032} & \multicolumn{2}{|c|}{0.011} & $<0.0001$ & $<0.0001$ \\
\hline
\end{tabular}

Sw - Swimmers, C - Control, min - minimum value, max - maximum value, $\bar{X}$ - arithmetic mean, SD - standard deviation, ss - statistical significance.

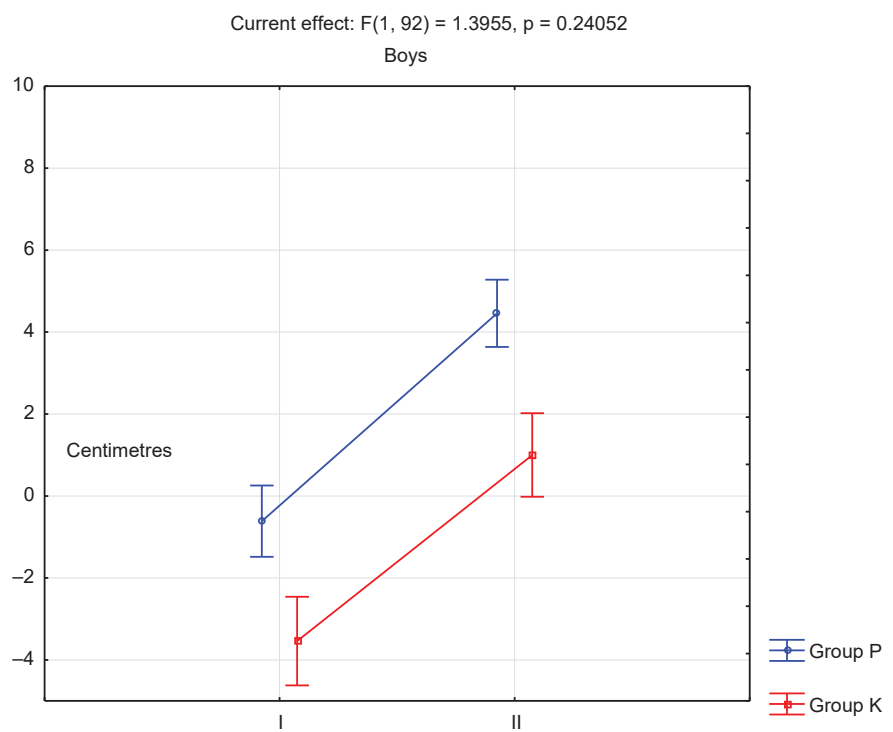

Figure 3. Changes in results of the Sit-and-Reach Test (flexibility) in Swimmers (Sw) group and Control (C) group 


\section{Standing Broad Jump Test - explosive leg power}

Swimmers group displayed statistically significantly better results in Examination I and II in terms of standing broad jump. Examination II proved statistically significant improvement of results in both groups (Sw, C) in comparison to Examination I (Table 5). In the Swimming Group, it was on average $12.2 \mathrm{~cm}$, while in the Control group it was $14.2 \mathrm{~cm}(p=0.271)$ (Figure 4).

Table 5. Descriptive characteristics of Standing Broad Jump Test (explosive leg power) results in the Swimmers (Sw) group and Control (C) group

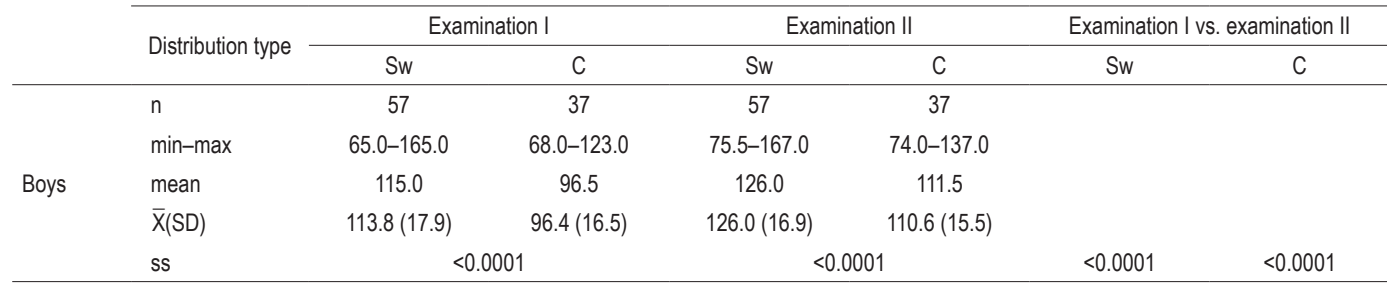

Sw - Swimmers, C - Control, min - minimum value, max - maximum value, $\bar{X}$ - arithmetic mean, SD - standard deviation, ss - statistical significance.

Current effect: $F(1,92)=1.2239, p=0.27149$

Boys

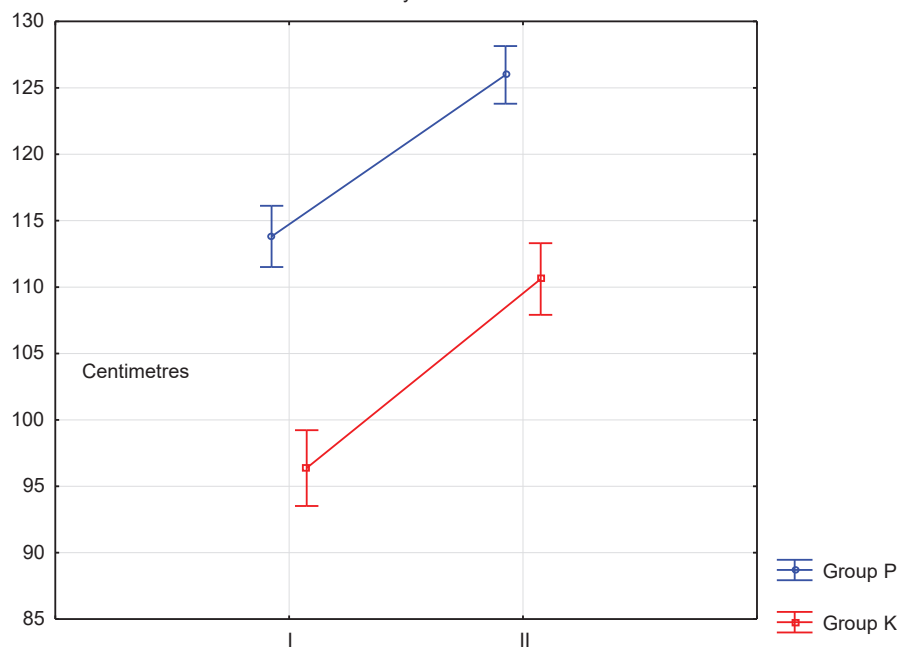

Figune 4. Changes in the results of Standing Broad Jump Test (explosive leg power) in the Swimmers (Sw) group and Control (C) group 


\section{Handgrip strength test - static strength}

Examination I revealed that in both groups (Sw, C) handgrip strength was identical. In Examination II statistically insignificantly better result was obtained by the Swimmers group. Examination II proved statistically significant improvement of results in both groups $(\mathrm{Sw}, \mathrm{C})$ in comparison to Examination I (Table 6). In the Swimmers group, it was on average 1.1 (psi - measurement in pounds per square inch), while in the Control group it was 0.8 ( $p s i$ - measurement in pounds per square inch) $(p=0.010)$ (Figure 5).

Table 6. Descriptive characteristics of Handgrip Strength Test (static strength) results in the Swimmers (Sw) and Control (C) groups

\begin{tabular}{|c|c|c|c|c|c|c|c|}
\hline & \multirow{2}{*}{ Distribution type } & \multicolumn{2}{|c|}{ Examination I } & \multicolumn{2}{|c|}{ Examination II } & \multicolumn{2}{|c|}{ Examination I vs. examination I } \\
\hline & & Sw & $\mathrm{C}$ & Sw & C & Sw & $\mathrm{C}$ \\
\hline \multirow{5}{*}{ Boys } & $n$ & 57 & 37 & 57 & 37 & & \\
\hline & $\min -\max$ & $0.5-5.0$ & $1.0-5.0$ & $1.5-6.0$ & $2.0-5.5$ & & \\
\hline & mean & 2.5 & 2.5 & 3.5 & 3.5 & & \\
\hline & $\bar{X}(S D)$ & $2.6(0.9)$ & $2.6(0.8)$ & $3.7(1.0)$ & $3.4(0.7)$ & & \\
\hline & ss & \multicolumn{2}{|c|}{0.967} & \multicolumn{2}{|c|}{0.175} & $<0.0001$ & $<0.0001$ \\
\hline
\end{tabular}

Sw - Swimmers, C - Control, min - minimum value, max - maximum value, $\bar{X}$ - arithmetic mean, SD - standard deviation, ss - statistical significance.

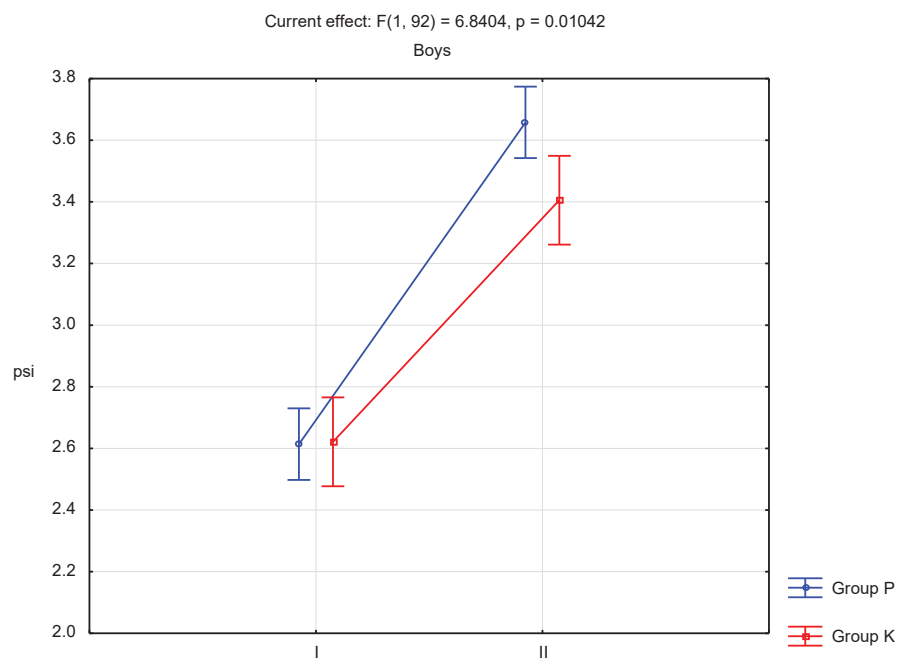

Figure 5. Changes in Handgrip Strength Test (static strength) results in the Swimmers (Sw) and Control (C) groups 


\section{Sit-Up Test - torso strength}

Swimmers group displayed statistically significantly better results in Examination I and II in terms of sit-up test. Examination II proved statistically significant improvement of results in both groups (Sw, C) in comparison to Examination I (Table 7). In the Swimmers group, it was on average $7.4(\mathrm{n})$, while in the Control group it was $6.5(\mathrm{n})$ $(p=0.148)$ (Figure 6).

Table 7. Descriptive characteristics of Sit-Up Test (torso strength) results in the Swimmers (Sw) and Control (C) groups

\begin{tabular}{|c|c|c|c|c|c|c|c|}
\hline & \multirow{2}{*}{ Distribution type } & \multicolumn{2}{|c|}{ Examination I } & \multicolumn{2}{|c|}{ Examination II } & \multicolumn{2}{|c|}{ Examination I vs. examination II } \\
\hline & & Sw & C & Sw & C & Sw & C \\
\hline \multirow{5}{*}{ Boys } & $n$ & 57 & 37 & 57 & 37 & & \\
\hline & $\min -\max$ & $0.0-20.0$ & $0.0-21.0$ & $5.0-29.0$ & $2.0-26.0$ & & \\
\hline & mean & 13.0 & 10.0 & 20.0 & 17.0 & & \\
\hline & $\bar{X}(S D)$ & $12.4(4.9)$ & $9.8(5.3)$ & $19.8(5.1)$ & $16.3(5.6)$ & & \\
\hline & ss & \multicolumn{2}{|c|}{0.020} & \multicolumn{2}{|c|}{0.002} & $<0.0001$ & $<0.0001$ \\
\hline
\end{tabular}

Sw - Swimmers, C - Control, min - minimum value, max - maximum value, $\bar{X}$ - arithmetic mean, SD - standard deviation, ss - statistical significance.

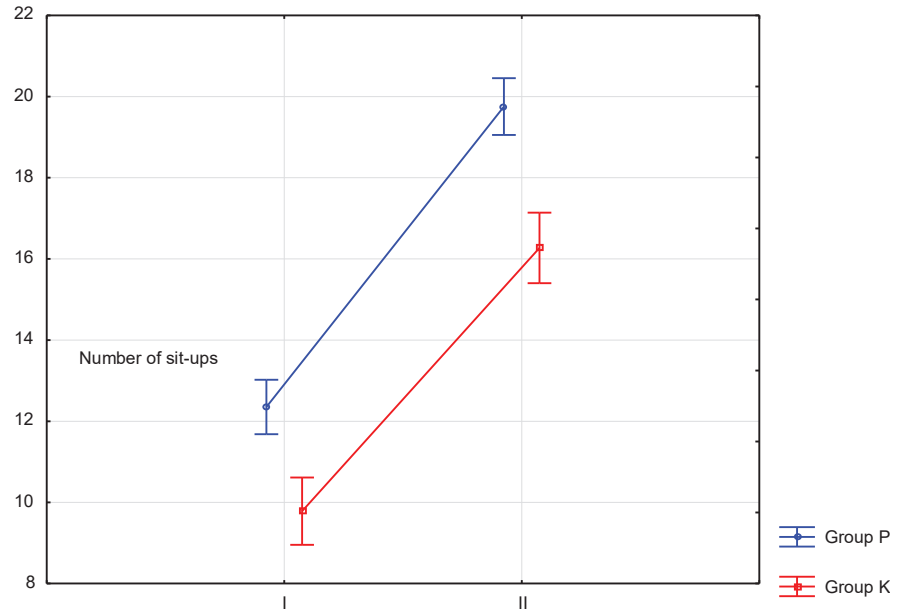

Figule 6. Changes in Sit-Up Test (torso strength) results in the Swimmers (Sw) and Control (C) groups 


\section{Bent Arm Hang Test - functional strength}

Swimmers group displayed statistically significant better results in Examination I and II in terms of bent arm hang. Examination II proved statistically significant improvement of results in both groups (Sw, C) in comparison to Examination I (Table 8). In the Swimmers group, it was on average $3.9 \mathrm{~s}$, while in the Control group it was $2.3 \mathrm{~s}$ $(p=0.0009)$ (Figure 7).

Table 8. Descriptive characteristics of Bent Arm Hang Test (functional strength) results in the Swimmers (Sw) group and Control (C) group

\begin{tabular}{|c|c|c|c|c|c|c|c|}
\hline & \multirow{2}{*}{ Distribution type } & \multicolumn{2}{|l|}{ Examination I } & \multicolumn{2}{|l|}{ Examination II } & \multicolumn{2}{|c|}{ Examination I vs. examination II } \\
\hline & & Sw (seconds) & C (seconds) & Sw (seconds) & C (seconds) & Sw & $\mathrm{C}$ \\
\hline & $\mathrm{n}$ & 57 & 37 & 57 & 37 & & \\
\hline & $\min -\max$ & $2.1-28.7$ & $0.7-20.5$ & $4.9-34.8$ & $2.7-17.6$ & & \\
\hline \multirow[t]{3}{*}{ Boys } & mean & 10.7 & 6.9 & 13.7 & 8.1 & & \\
\hline & $\bar{X}(\mathrm{SD})$ & $11.7(5.8)$ & $6.8(4.5)$ & $15.6(6.2)$ & $9.1(4.1)$ & & \\
\hline & ss & \multicolumn{2}{|c|}{$<0.0001$} & \multicolumn{2}{|c|}{$<0.0001$} & $<0.0001$ & $<0.0001$ \\
\hline
\end{tabular}

Sw - Swimmers, C - Control, min - minimum value, max - maximum value, $\bar{X}$ - arithmetic mean, SD - standard deviation, ss - statistical significance.

Current effect: $F(1,92)=11.909, p=0.00085$

Boys

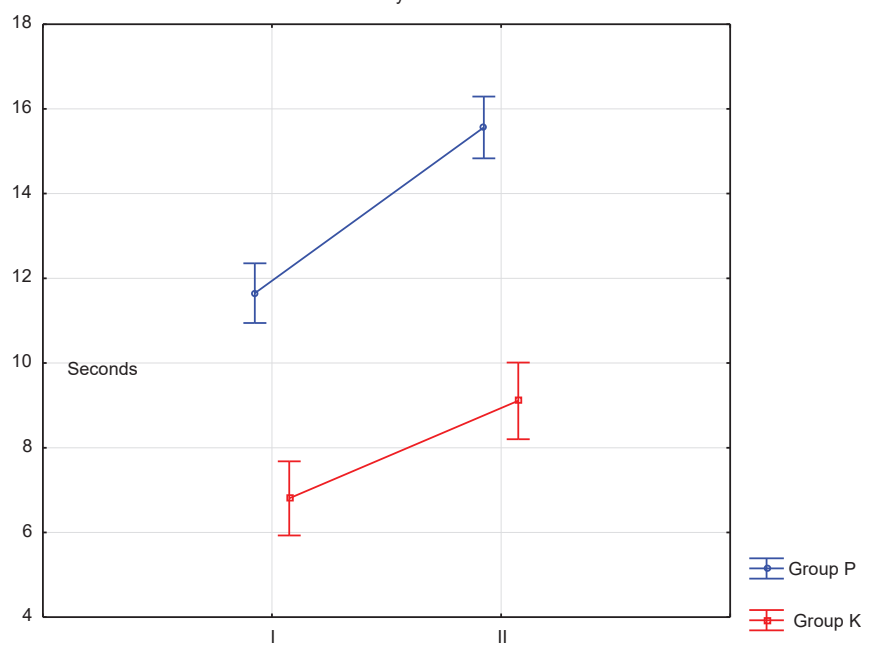

Figure 7. Changes is Bent Arm Hang Test (functional strength) results in the Swimmers (Sw) group and Control (C) group 


\section{$10 \times 5$ m Shuttle Run Test - agility Pun}

In Examination I the average results of the shuttle run were statistically insignificantly better in the Swimmers group, while in Examination II the statistical difference was significant. Examination II proved statistically significant improvement of results in both groups (Sw, C) in comparison to Examination I (Table 9). In the Swimmers group, it was on average $2.7 \mathrm{~s}$, while in the Control group it was $2.2 \mathrm{~s}(\mathrm{p}=0.259)$ (Figure 8).

Table 9. Descriptive characteristics of $10 \times 5 \mathrm{~m}$ Shuttle Run Test (agility run) results in the Swimmers (Sw) group and Control (C) group

\begin{tabular}{|c|c|c|c|c|c|c|c|}
\hline & \multirow{2}{*}{ Distribution type } & \multicolumn{2}{|c|}{ Examination I } & \multicolumn{2}{|c|}{ Examination II } & \multicolumn{2}{|c|}{ Examination I vs. examination II } \\
\hline & & Sw (seconds) & C (seconds) & Sw (seconds) & C (seconds) & Sw & C \\
\hline \multirow{5}{*}{ Boys } & $n$ & 57 & 37 & 57 & 37 & & \\
\hline & $\min -\max$ & $18.5-33.0$ & $21.3-35.5$ & $17.4-29.7$ & $20.0-32.9$ & & \\
\hline & mean & 26.2 & 27.2 & 23.7 & 25.1 & & \\
\hline & $\bar{X}(S D)$ & $26.4(3.2)$ & $27.5(3.2)$ & $23.7(2.9)$ & $25.3(2.8)$ & & \\
\hline & ss & \multicolumn{2}{|c|}{0.071} & \multicolumn{2}{|c|}{0.016} & $<0.0001$ & $<0.0001$ \\
\hline
\end{tabular}

Sw - Swimmers, C - Control, min - minimum value, max - maximum value, $\bar{X}$ - arithmetic mean, SD - standard deviation, ss - statistical significance.

Current effect: $F(1,92)=1.2914, p=0.25874$

Boys

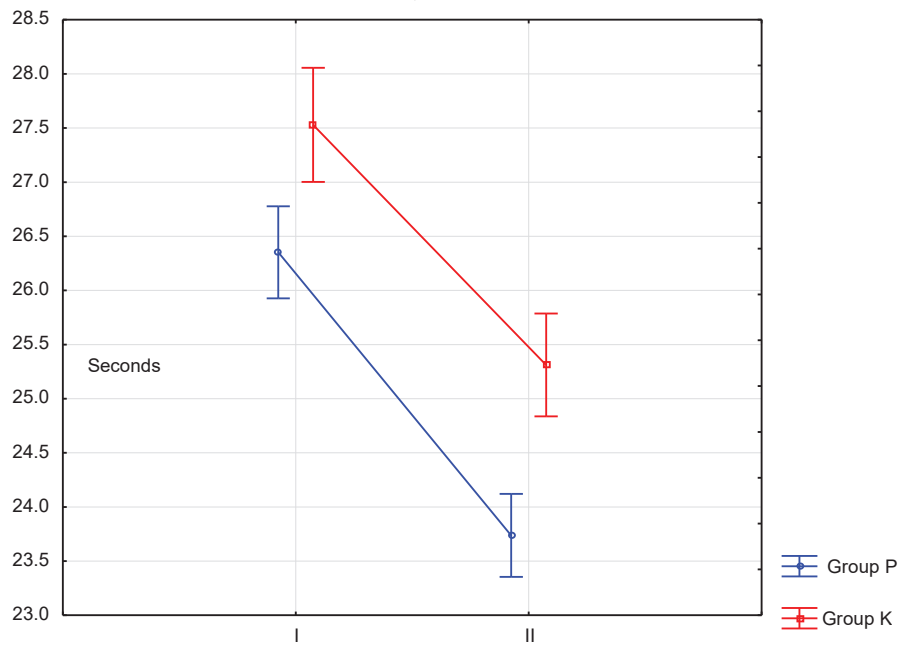

Figure 8. Changes in $10 \times 5 \mathrm{~m}$ Shuttle Run Test (agility run) results in the Swimmers (Sw) group and Control (C) group) 


\section{Discussion}

The research revealed changes in both groups (Sw, C) in terms of all eight tests. Examination II proved statistically significant improvement of results in both groups $(\mathrm{Sw}, \mathrm{C})$ in comparison to Examination I. Comparing the Swimmers and Control groups, the dynamics of changes between Examination I and II was greater among Swimmers only in balance, static strength and functional strength tests. In groups (Sw, C), differences between results of Examination I and II were similar in terms of speed of upper limb movement, agility, explosive strength, torso strength and agility run. Pietrusik's research (1981) confirmed that boys in Swimmers groups displayed significant improvements in final results of all physical ability tests. Pietrusik (1997) believes that better motor skills '...of girls and boys from the Swimmers groups in the final examination do not result from unique motor predispositions, but rather from specialized swimming exercises performed by children during the swimming training process' (Pietrusik 1997: 33). The Swimmers group did not attain better dynamics of changes in all tests than their peer Control group ( i.e. speed of upper limb movement, agility, explosive strength, torso strength, agility run). Progressive changes in motor skill of subjects were a positive phenomenon in the physical development of children. During both Examinations (I and II), subjects attended elementary school $1^{\text {st }}$ grade, i.e. the first grade of the early school age (Osiński 2011). Przewęda (1981: 164) described this period, saying that '...school takes over the role of a provider of factors that influence children and it needs to fulfill their biological motor needs'. According to Przewęda (1981: 164), children display a great 'need to blow off steam by physical activity, to satisfy their great hunger for activity.' Parents of children at early school age serve as 'stimulators' of development. It is their duty to provide children with additional sports classes. Based on child's interests, sports predispositions, family (sports) traditions, often it is the parent who choose a particular activity for the child, e.g. sports club, dancing club etc. Participation in organized, regular sports classes results in the development of motor (physical) skills of children (Torrance et al. 2007; Chalcarz et al. 2008; Wilk, Eider 2014).

\section{Conclusions}

1. In both groups (Sw, C) there was a statistically significant improvement of results of all motor skill tests in Examination I and II.

2. In Examination I and II, the Swimmers group displayed higher motors skills than Control group in terms of: overall balance, upper limb movement speed, agility, explosive strength, torso strength, functional strength and agility run (Figures 1, 2, 3, 4, 6, 7, and 8 ).

3. Dynamics of changes between Examination I and II was the greatest among Swimmers in the following tests: overall balance, static strength, and functional strength (Figures 1, 5, 7). It was similar in the remaining 5 tests: upper limb movement speed, agility, explosive strenght, torso strength, and agility run (Figures 2, 3, 4, 6, 8).

4. Progressive changes in motor skill of subjects is a positive phenomenon in the physical development of a child.

5. Swimming training resulted significantly in positive changes in terms of motor skills of boys who were at the initial stage of swimming trainings, compared to their non-training peers. 


\section{References}

Ankieta z działalności sportowej klubu w 2012 roku. Miejski Klub Pływacki. Szczecin 2013.

Chalcarz W., Merkiel S., Pach D., Lasak Ż. Charakterystyka aktywności fizycznej poznańskich dzieci w wieku szkolnym. Medycyna Sportowa. 2008; 24 (5): 318-329.

Drozd M. Droga do sukcesów. In: 60 lat Zachodniopomorskiego Okręgowego Związku Pływackiego 1947-2007, eds. T. Rek, W. Taczalski. SAR Paweł i Robert Chudkowie. Szczecin 2007.

Eider P. Reserch Analysis of Selection Criteria at the Initial Stage of Swimming Tranning of Primary School Junior Students. Centr Eur J Sport Sci. 2015; 11 (3): 55-62.

Eider P. Selection in swimming traning - theoretical study. No. 1 in Szczecin. Centr Eur J Sport Sci. 2014; 5 (1): 65-75.

Eider J., Eider P. Olimpijczycy i paraolimpijczycy województwa zachodniopomorskiego Londyn 2012. PPH Zapol, Szczecin 2012.

Eider J. Olimpijczycy i paraolimpijczycy województwa zachodniopomorskiego - Pekin 2008. Wydawnictwo Naukowe Uniwersytetu Szczecińskiego, Szczecin 2009.

Grabowski H., Szopa J. EUROFIT. Europejski Test Sprawności Fizycznej. AWF, Kraków 1991.

Janicka M., Lewandowski P. (ed.) Londyn 2012 Igrzyska XXX Olimpiady. PKOI, Warszawa 2012.

Opyrchał C., Karpiński R., Sachnowski K. Proces wieloletniego szkolenia pływaków wysokiej klasy. Sport Wyczynowy. 2005; 9-10: $57-67$.

Osiński W. Teoria wychowania fizycznego. AWF, Poznań 2011.

Osiński W. Antropomotoryka. AWF, Poznań 2003.

Pietrusik K. Zmienność sprawności motorycznej u dzieci poddanych procesowi nauczania pływania. In: Sport pływacki i lekkoatletyczny w szkole (Wrocław-Srebrna Góra 1995), eds. P. Kowalewski, J. Migasiewicz. AWF, Wrocław 1997: 27-39.

Pietrusik K. Kształtowanie się sprawności motorycznej oraz wydolności fizycznej u dzieci uprawiających pływanie sportowe. Roczniki Naukowe AWF, Poznań 1981; 30: 107-125.

Przewęda R. Rozwój somatyczny i motoryczny. WSiP, Warszawa 1981.

Sprawozdanie z działalności Polskiego Związku Pływackiego za okres 21.11.2008-19.10.2012 Polski Związek Pływacki, Warszawa 2012.

Torrance B., McGuire K.A., Lewanczuk R., McGavock J. Overweight, physical activity and high blood pressure in children: a review literature. Vasc Health Risk Manag. 2007; 3 (1): 139-149.

Wilk K., Eider P. The evaluation of motor skills of 1-4 grade music-oriented male students in Primary School Complex No. 2 in Szczecin. Centr Eur J Sport Sci. 2014; 6 (2): 35-58.

Volbekiene V.G. Health-related physical fitness among schoolchildren in Lithuania: A comparison from 1992 to 2002. $2007 ; 35$ (3): $235-242$.

Vranešić-Hadžimehmedović D., Mahmutović l., Bajramović l., Jelešković E. The Partial Quantitative Changes in Swimming Preformance and Basic Motor Abilities of Young Girls Under the Influence of the Experimental Program, Homo Sporticus. 2012; 14 (2): 41-52.

Cite this article aS: Eider P. Changes in Motor Skills of Boys who Trained Sports Swimming in an Annual Training Cycle. Central European Journal of Sport Sciences and Medicine. 2015; 12 (4): 121-133. 
